Archived version from NCDOCKS Institutional Repository http://libres.uncg.edu/ir/asu/

\title{
Appalachľan
}

$\overline{B \text { O O N E, N O R T H C A R O L I N A }}$

\section{The Discursive Construction Of The Gamification Of Journalism}

\author{
By: Tim P. Vos and Gregory P. Perreault
}

\begin{abstract}
This study explores the discursive, normative construction of gamification within journalism. Rooted in a theory of discursive institutionalism and by analyzing a significant corpus of metajournalistic discourse from 2006 to 2019 , the study demonstrates how journalists have negotiated gamification's place within journalism's boundaries. The discourse addresses criticism that gamified news is a move toward infotainment and makes the case for gamification as serious journalism anchored in norms of audience engagement. Thus, gamification does not constitute institutional change since it is construed as an extension of existing institutional norms and beliefs.
\end{abstract}

Vos TP, Perreault GP. The discursive construction of the gamification of journalism. Convergence. 2020;26(3):470-485. doi:10.1177/1354856520909542. Publisher version of record available at: https://journals.sagepub.com/doi/full/10.1 177/1354856520909542 


\title{
The discursive construction of the gamification of journalism
}

Convergence: The International Journal of Research into New Media Technologies 2020, Vol. 26(3) 470-485 (C) The Author(s) 2020 Article reuse guidelines: sagepub.com/journals-permissions DOI: I0.1 I77// 354856520909542 journals.sagepub.com/home/con

@SAGE

\section{Tim P Vos}

Michigan State University, USA

\section{Gregory P Perreault (1)}

Appalachian State University, USA

\begin{abstract}
This study explores the discursive, normative construction of gamification within journalism. Rooted in a theory of discursive institutionalism and by analyzing a significant corpus of metajournalistic discourse from 2006 to 2019, the study demonstrates how journalists have negotiated gamification's place within journalism's boundaries. The discourse addresses criticism that gamified news is a move toward infotainment and makes the case for gamification as serious journalism anchored in norms of audience engagement. Thus, gamification does not constitute institutional change since it is construed as an extension of existing institutional norms and beliefs.
\end{abstract}

\section{Keywords}

Boundary work, discourse analysis, discursive institutionalism, gamification, gamifying news, institutional change, journalism studies, journalistic norms, metajournalistic discourse

US journalists have largely made a turn toward their audience, experimenting with and adopting a range of audience-focused initiatives (Batsell, 2015). At the same time, many journalists remain reluctant to embrace a radical renegotiation of the journalist-audience relationship, in part, fearing commercial motives are at the core of such initiatives and will ultimately undercut or dilute journalism's normative obligations (Borger et al., 2013). It's unclear where the so-called gamification of journalism - the combination of game designs and dynamics with news content on digital news platforms - stands within this broader outlook (Ferrer-Conill and Karlsson, 2016). While scholars have debated this question (see Ferrer-Conill and Karlsson, 2016, for an overview), journalists' own outlook is still little understood, either in journalism practice or journalism studies. Given past misgivings about audience-facing journalistic innovations (Schmidt, 2019), we could plausibly expect that journalists themselves might see gamification as building civic

\section{Corresponding author:}

Tim P Vos, School of Journalism, Michigan State University, 404 Wilson Road, Room 305, East Lansing, MI 48824, USA. Email: vost@missouri.edu 
knowledge and engagement or as commercially inspired edutainment. So, how do journalists place gamification within journalism's normative boundaries? And can we learn something about journalism's normative boundaries more broadly, by examining the case of gamification?

We situate this study within a theoretical framework of discursive institutionalism (Schmidt, 2008,2010 ), which we outline below as a precursor to a broader discussion of the place of discourse within journalism and about the phenomenon of gamification. The purpose of this study is to explore the discursive, normative construction of gamification within the institution of journalism, particularly within journalism's trade press and in broadly circulated news articles. Journalists used the trade press and the pages and sites of their own news outlets to discuss new developments - particularly those that involve some degree of renegotiation of the journalistaudience relationship - and explicitly or implicitly accept or challenge these developments. Hence, this study examines a significant corpus of mostly US journalists' own discourse about gamification to examine the ways it is defined, how gamification is situated within journalism's institutional purposes and boundaries, and how journalism's own institutional identity comes to bear in the gamification discourse.

The value of this study, then, is in a more elaborate understanding of how institutional actors use discursive resources to negotiate institutional maintenance or change. Indeed, we maintain one cannot theorize journalistic change itself apart from journalistic discourse.

\section{Theory and literature}

Here we review the literature on gamification's place within journalism, paying attention to how gamification fits into moral discourses about journalism's social obligations. This study is premised on the notion that journalism is a discursive institution (Hanitzsch and Vos, 2017) and hence frames our empirical inquiry into gamification through the lens of discursive institutionalism (Schmidt, 2010). We set out the basic contours of discursive institutionalism, how this framework is suited to the normative nature of journalism's identity, how discourse is an essential feature of journalistic norms, and how gamification comes into the picture. Journalism, of course, is a material reality, as is the gamification of journalism. But, as an institution, the '-ism' of journalism is an essential feature. Journalism, like other institutions, is anchored by norms and beliefs that are manifested in discourse. To understand the discourse is to understand something essential about the institutional legitimacy of gamification, but also about journalism's broader institutional value system.

\section{Gamification of journalism}

Gamification, while anchored in a long history, is generally construed as part of the digital innovations entering journalism in the 21 st century. Here we point out how gamification has evolved, particularly how its meaning has become more elaborate and how debates about its risks and benefits have taken shape. We note how news games have sat uneasily within journalism's dominant belief systems.

While the gamification of news is often positioned as a recent innovation, it should be pointed out that gamification in news is not new. However, historically, it was little more than simple games, such as quizzes and crosswords (Bogost et al., 2010). Journalism's digital transition has opened up new possibilities for adapting digital games to journalism - a transition that has been 
imbued with much hope, but also with some concerns. Digital games, for example, have sometimes been seen as distracting citizens from using news media (Putnam, 2000).

For scholars, gamification is an 'approach to design' (Seaborn and Fels, 2015: 28) that emphasizes using 'motivational affordances in order to invoke gameful experiences and further behavioral outcomes' (Hamari et al., 2014: 2). In short, gamification is the process of making activities function like a game (Werbach, 2014); this is in contrast to the related concept of news games, which are full games used to 'participate in the public sphere' (Ferrer-Conill and Karlsson, 2016: 15-16). Both share the related mission of conveying current events in an 'engaging manner to an audience that responds and is engaged by the language of video games' (Ferrer-Conill and Karlsson, 2016: 15-16).

Historically, gamification had two precursor movements. In the mid-20th century, the Soviet Union experimented with a 'workplace-based socialist competition' hoping that the power of games could replace capitalist competition with something more humane, but would similarly motivate productivity (Nelson, 2012: 23). Similarly, in the 1990s and 2000s in America, businesses promoted a "trend of "fun at work" that reimagined the workplace as a fun and playful locale' (Nelson, 2012: 23).

Gamification has become a buzzword in numerous industries interested in invoking the experiences that games provide, such as in healthcare (King et al., 2013), education (Nicholson, 2015), business (Houtari and Hamari, 2012), and technology (Fujiawa and Manki Min, 2013). Yet, some manifestations of gamification have also drawn significant criticism that they fail to fulfill the essential functions of a game and fail to accomplish the goals of the 'marketers and consultants who seek to...exploit an opportunity for benefit' (Bogost, 2015: 65). Bogost (2015) argues that numerous industries are attracted to gamification given that it seems to take a potential competitor - games - and utilize it for their own purposes. In many industries, games are seen as 'magic attention machines, inspiring players to devote tens or hundreds of hours to them. Yet the cost, complexity, and unfamiliarity of games makes them seem risky, expensive, and confusing' (Bogost, 2015: 67). Bogost (2015) describes gamification as 'exploitation ware', in that the term more adequately characterizes the goals of those who promote it - to exploit audience expectations as well as the expectations of those who hire consultants to implement the process. Thus, Bogost (2015: 77) sees the process as 'bullshit because its very interpretation and purpose are bullshit'. Gamification, then, is drawn into a normative, moralizing discourse.

Yet it is hard to fault journalists for recognizing that 'game developers know better than anyone else how to inspire' and that 'game design isn't just a technical craft. It's the twenty-first century way of thinking and leading' (McGonigal, 2011: 13). And while earlier forms of gamification such as quizzes - have been successfully translated into digital news, it is video games that are reported to be 'majorly engaging younger audiences' (Ferrer-Conill and Karlsson, 2016: 7). In short, gamification in journalism aims for a less business-oriented goal than much of what Bogost (2015) critiques, since the news media need to 'find methods that engage users to be informed' (Ferrer-Conill and Karlsson, 2016: 8). Here we see a possible new normative anchor for gamification - attaching it to the legitimacy of audience engagement as a normative obligation (Holton et al., 2016; Lawrence et al., 2018).

Ferrer-Conill and Karlsson (2016) see the 'gamified news service' as having the potential to engage users - particularly younger users - with the news. Yet, Ferrer-Conill and Karlsson (2016: 10) acknowledge that gamification would likely face pushback in the journalistic field given that games could be perceived as a 'threat to creative journalism, selling core values of journalism to 
entertainment media'. In other words, they anticipate that gamification will have to navigate a normative, discursive landscape to be seen as legitimate journalism.

\section{Journalism as a discursive institution}

Here we set out the framework of discursive institutionalism (Schmidt, 2008, 2010), paying particular attention to the role of discourse in institutional legitimacy and institutional change. We also show how notions of metajournalistic discourse (Carlson, 2016) can be usefully employed within discursive institutionalism, and why institutional norms are essential discursive artifacts. In brief, we argue that to understand how gamification fits within journalism's institutional boundaries, it is appropriate to attend to how journalists discursively construct gamification.

Discursive institutionalism builds on two related notions: an institution is a system of rules, norms, and beliefs (Parsons, 2007) and this system is manifested in verbal and written expression and discussion (Schmidt, 2008). Journalism is an institution in as much as it is 'a site of systematized principles of action enduring across time and supervising a central area of social and political life' (Cook, 1998: 15). These systematized principles are what link persons together in a shared experience and shared outlook. Journalism has long been understood to be driven by routines and typifications (Tuchman, 1978). In other words, journalists have been socialized into the institution of journalism, which then structures how journalists think about and do their work (Hanitzsch and Vos, 2017). These principles and rules are sometimes explicit, but often remain implicit until disruptions or innovations of various kinds force them to be enunciated.

Principles, rules, and norms play an important role in establishing legitimacy for both an institution and its various institutional actors (Parsons, 2007). Because of journalism's historical role in establishing the veracity of truth claims made by political, economic, and other social actors, these same actors are often motivated to either establish or challenge journalism's social authority (Carlson, 2017). Thus, journalists have had to discursively negotiate and establish their own legitimacy (Zelizer, 2004). This is a process whereby journalists tap into society's broader legitimizing discourses. So, for example, journalists have defined their legitimacy in terms of their contribution to democracy (Schudson, 2001) and modernity (Vos, 2012) and by way of their adherence to scientifically valid procedures (Schudson, 1978). Legitimacy, then, is expressed in institutional scripts - or discourses - such as, being a 'watchdog of the public interest' or 'democracy dies in darkness'. Legitimacy hinges on the social resonance of these discourses and the institution's ability to overcome competing discourses, such as 'yellow journalism' and journalism is 'all about the money'. Indeed, it is precisely because journalism has often been caught in competing narratives - typically distilled to the goals of enriching the public sphere or enriching private publishers - that the discursive fate of gamification is particularly interesting. How gamification fairs in this discursive tension speaks to its institutional legitimacy.

Institutional discourse plays a particularly important role within journalism. While most professions have accrediting and licensing standards that codify certain institutional norms and practices, journalism is rarely delimited in such fashion, particularly in the United States. Based on principles of press freedom, journalists have eschewed formalized norms, rules, and boundaries, lest these be used to limit journalistic autonomy. Nevertheless, journalists self-police the field through their informal discourse, marking various actions and actors as either comporting to institutional principles and norms or not.

Gamification's institutional fate is no less consequential because of journalism's own institutional instability. The opposite is true. While some point to the deinstitutionalization of journalism, 
evidence suggests that journalistic rules, norms, and beliefs remain resilient (Picard, 2014). Deinstitutionalization is actually a naturally occurring process whereby institutions reinstitutionalize to accommodate disruptions (Picard, 2014). In fact, because the institution of journalism is inherently social and because discourse is at the heart of its institutional identity, its discourse is the means to negotiate change, including changes such as gamification. Thus, examining institutional discourse provides 'insights into the dynamics of institutional change by explaining the actual preferences, strategies, and normative orientations of actors' (Schmidt, 2010: 1). So, for example, journalists have discursively struggled to situate entrepreneurial journalism - some emphasizing how it falls outside traditional institutional norms, others stressing new normative imperatives (Vos and Singer, 2016). Journalists' discourses, then, can try to situate emergent practices within existing norms, or they can try to reconfigure the norms.

Journalism's institutional discourse, which has also been called metajournalism, is 'the site in which actors publicly engage in processes of establishing definitions, setting boundaries, and rendering judgments about journalism's legitimacy' (Carlson, 2016: 350). Such discourse appears via news media outlets - in media-related columns or discussion programs - journalism trade journals and sites, journalists' social media posts, and wherever else journalists discuss journalism, including face-to-face discussions. Some of the discourse is directly, outward facing; while other discourse is inward - among journalists - but nevertheless indirectly engaged with imaginary or real public interlocutors (Vos, 2016).

Like a theory of discursive institutionalism, Carlson (2016) stresses that metajournalistic discourse is both a structurated context that shapes how journalists think and talk about their work and a site of journalistic agency (Schmidt, 2010). Journalists have discursive tools at their disposal and they can use these tools strategically when confronting new phenomena, such as gamification. 'Discourses morph and change, with new articulations arising through emergent understandings and material changes' (Carlson, 2016: 353). A central concept in the literature, then, is that discourse is adaptable. This adaptability allows journalists to steer journalism through a changing institutional terrain - a terrain that is structured by journalistic norms, rules, and principles.

While much of journalism's ways of operating are taken for granted, journalistic norms are necessarily explicit (Schudson, 2001). Norms have moral force only in as much as they are articulated and held out as guides to what is proper, right, and good (Artemas et al., 2018). Even practices that are accepted as common and normal might still nevertheless be seen as violating normative principles (Schudson, 2001). News organizations act in their self-interest on a fairly regular basis; however, they are also regularly admonished for doing so because it is believed such behavior compromises journalism's public service obligations (Kovach and Rosenstiel, 2014). In other words, discourse is used to imbue journalistic practices with moral meaning. And while many competing institutional narratives are plausible, normative discourses have historically emphasized the morality of public service journalism and the immorality of economic self-interest. Indeed, newspapers' introduction of crossword puzzles was met with strong moral denunciations, even calling them 'a sinful waste' (Bogost et al., 2010: 86).

Indeed, journalism's economic goals, which often drive journalistic innovation, are a key source of normative tension. Thus, entrepreneurial journalism, for example, has been seen both as the way forward for an economically troubled institution and as problematic in light of normative, institutional scripts about a 'wall of separation' between business and editorial functions of news outlets (Coddington, 2015; Jukes, 2019; Vos and Singer, 2016). Whatever the innovation might be, journalists will likely be faced with interlocutors who will push journalists to situate that innovation within existing normative frameworks. Journalism's normative parameters - if they are 
truly normative - will be manifested in discourse (Schudson, 2001), and thus naturally occurring metajournalistic discourse is the appropriate setting to explore journalism as an institutional phenomenon (Hanitzsch and Vos, 2017) and gamification as an institutional innovation.

\section{Research questions}

Returning to Carlson's (2016: 350) summation: journalistic discourse is about 'establishing definitions, setting boundaries, and rendering judgments about journalism's legitimacy'. With this in mind, we pose the following questions to explore in this study:

RQ1: What have journalists meant by gamification?

RQ2: How have journalists discursively placed gamification within the institutional practices and norms of journalism?

RQ3: How have journalists discursively legitimized or delegitimized gamification and what does this say about journalism?

The goal is both interpretation and explanation. RQ1 is posed in descriptive terms - asking about journalists' definitions of gamification - but by interpreting how gamification is defined (rather than just describing various definitions), we get a sense of the normative context in which mean making occurs. RQ2 seeks an understanding of how journalists' institutional norms explain how journalists place gamification within journalism's moral boundaries, but also leaves open journalists' discursive adaptability to reconfigure those boundaries. RQ3 seeks explanations for how discursive resources can be used to portray gamification's relative legitimacy, and thus hearkens back to journalism's broader values. Thus, while RQ2 focuses on the moral status of gamification, RQ3 focuses on the moral landscape of journalism. Taken together, the questions seek an elaboration of discursive institutional theory within the realm of journalism. They do so by exploring the institutional purchase of journalistic norms and beliefs and the discursive resources available to accomplish institutionalization.

\section{Study design}

Based on a framework of discursive institutionalism (Hanitzsch and Vos, 2017; Schmidt, 2008, 2010), it is only fitting that the study analyze the discourse of journalism or metajournalistic discourse. Discourse analysis pays particular attention to 'language in use' (Candlin, 1997: ix) and language in its 'institutional context' (Fairclough, 1995: 50), in this case naturally occurring institutional language about gamification. Discourse analysis treats texts as a 'negotiation' and 'a site of struggle over meaning' (Fürsich, 2009: 244). In other words, discourse is a kind of collective meaning-making among interlocutors that emerges over time. Indeed, it is important to attend to the temporal context and sequences of discourse, since the analysis of the sequence of texts can 'explain the implications of previous discursive positions on subsequent ones' (Carvalho, 2008: 163).

While there are multiple forms of metajournalistic discourse, this study focuses on two kinds of institutional discourse - journalists' news stories about the gamification of journalism, and on stories, posts, and comments in the journalism trade press. Discourse about gamification has been collected from news outlets using the ProQuest searchable database and from the journalism trade press using a custom searchable database. Both databases focus mostly on the United States, but 
not exclusively so. The ProQuest search focused on articles in daily news outlets. The outlets ranged from major dailies, such as The Wall Street Journal to smaller and regional papers, such as The Daily Herald (Arlington Heights, Illinois, USA). The trade press database was created by using a web scraper to download and archive articles and posts from 25 sites where journalists discuss journalism. A network analysis indicated the most trafficked sites and how the sites' connected to each other. These included sites such as American Journalism Review, Editor \& Publisher, MediaShift, and NiemanLab. The goal was to choose sites that represented institutional discourse and eliminate sites that were at the margins of the institution.

From here, we used iterations of 'gamification' and 'journalism' as search terms to identify pieces that dealt with gamification and then removed articles written by non-journalists (e.g. both databases included pieces written by academics). The data amounted to a significant corpus of metajournalistic discourse (224 articles in the trade press and 207 articles from general news outlets) over the course of more than a decade (2006-2019). The time frame allows for ongoing debates to be tracked and the arc of the discourse to emerge. We started with 2006 because this was when the discourse about gamification first appeared (both databases go back further than this).

An inductive analysis involved looking for themes in the discourse, with awareness of the temporal and publication context (general news outlets vs. trade press). In the end, there was only one notable difference in discourse based on publication context, and that was a difference within the trade press (more on this in the analysis). The coauthors each analyzed portions of the discourse and then compared themes, returning to each portion of the texts to see if themes found in one portion of the discourse were also apparent in the other portion of the texts. Since the findings are presented as institutional discourse - and for reasons of readability - we do not include full citations for the metajournalistic discourse that follows. We do indicate the year in which the discourse appears as a means of context.

\section{Discourse on gamification}

It is clear that the discourse about gamification is indeed a 'negotiation' (see Fürsich, 2009) - it attempts to reconcile things that have historically represented different sets of values. Gamification, as one article noted, was part of an effort to 'combine two seemingly incompatible industries: gaming and the news' (2015). The metajournalistic discourse acknowledged that gaming is partly a marketing tactic, but also a means of meeting journalism's traditional social obligations. As one editor said, 'It appeals to the younger crowd but it's also another way of conveying information' (2015). While gamification was not without its critics, it was often defined and characterized in ways that positioned gamification within journalism's normative framework, anchored it to an emerging institutional norm of audience engagement, and in doing so, legitimized gamification as proper, right, and good. The discourse also positioned journalism as an adaptive, modern institution capable of pushing past old problems to meet its traditional social obligations.

\section{Characterizing gamification}

What did journalists mean by gamification? When journalists spoke to themselves in the trade press, characterizations were scant or brief, and only slightly more descriptive when speaking to a broader public through their own news outlets. Earlier definitions were generally more detailed than later descriptions, when readers would have presumably already known something about gamification. A 2006 definition referred to it as 'the use of game mechanics, feedback loops, and 
rewards to spur interaction and boost engagement, loyalty, fun and/or learning' (2006). Later descriptions were generally of the variety: Gamification 'adds game-like elements to activities that are not really games' (2014). The occasional description was more flippant: 'Think of it as Candy Crush for tracking police militarization or Flappy Bird to uncover government waste' (2015). There were no grand attempts at extensive definitions or typologies, as have appeared in the academic literature (see e.g. Bogost et al., 2010).

But aside from formal, or even flippant, definitions, the definitions that journalists offered also laid important context for how they wanted gamification to be understood. Thus, journalists also described gamification in terms of where it came from, pointing to the origins of gamification in the social networking app Foursquare, born in 2010, in which users competed to become the 'mayor' of local venues (2017). Others noted that a Knight News Challenge winner had championed gamifying news, giving gamification the heightened visibility and credibility that the Knight Foundation brought to journalistic innovations (2011).

An important feature of the definitions of gamification or gamifying news is in the characterizations of the phenomenon. What was gamification an example of? In many cases, journalistic discourse indicated that gamification is predominantly a business and marketing strategy. It was defined in relation to the 'consumer experience' - hence, as a tool of the marketplace (2014). Gamification in the journalists' estimation was a 'business trend' (2012). It was 'a natural progression that capitalises on this new market' (2015) - a market for games that was growing much faster than the economy as a whole. Furthermore, as a business trend, journalists often described it in relation to management objectives, given that they describe the opinion of the employee as fairly immaterial in the implementation of gamification: 'all evidence suggests that your work one day will operate like a videogame to be conquered, rather than a craft to be perfected' (2014). In short, this was not a grassroots movement within the workplace, but a strategically initiated process. This was particularly relevant in digital journalism, according to the discourse, given that social media allows 'my bosses' return-on-investment on my work [to be] measured' (2014). It was not an ennobling discourse; in fact, it was the basis for subsequent criticisms of gamification.

For many of the characterizations of the phenomenon, the focus was less on what gamification was than on what it did, that is, on the effects it produced or the goals it achieved. For example, the discourse defined the practice as an 'application of gaming to encourage certain types of behavior' (2017) and to 'build habits' (2016). Or it was described in terms of mental effects, such as 'immersion into the subject' (2015). It turned a 'traditionally boring process into a competition' (2011). The fun of gamification was, then, largely a 'veneer' (2014) - it was a means to achieve strategic ends. Those ends were often explained in altruistic terms; for example, news games could 'increase users' news literacy skills' (2018). Indeed, much of the discourse characterized gamification as a tool for audience engagement (more on this below).

These characterizations were also fleshed out in comparisons of gamification to other phenomena. Thus, gamification was like social media, which is designed to compel the user to 'interact over and over again' (2013). It was like clickbait, where people click a link for the 'same reason they keep playing slots: maybe this time it'll be good' (2016). These were not always the most flattering comparisons, but the discourse rarely used such comparisons to marginalize gamification. It should be noted that even as journalists defined gamification, many sought to locate the practice on a familiar footing that anticipated critical interlocutors. For example: Gamifying news was 'where video game technology and practises are used in conjunction with traditional journalism methods' (2015). 
In response to RQ1, definitions of gamification varied little and emphasized the use of the mechanics and experiences of games to engage audiences with the news. Taken together, gamification was not only defined, it was contextualized by where it came from, by what kind of activity it was, by what goals it achieved, and by comparison to other phenomena. Hence, even in the definitions of gamification, a moral groundwork was laid and subtle legitimization occurred. Gamified journalism was still journalism.

\section{Placing gamification within journalism}

At times, journalists adamantly placed gamification outside the realm of appropriate journalistic practices, locating it with profit-maximizing or other marginalized practices. Yet at other times, journalists passionately defended the practice, seeing it as entirely compatible with journalistic norms.

Journalistic discourse has long challenged actors and actions that tested the boundaries of traditional journalism (see Carlson, 2017). These challenges were apparent here too. As already noted, journalists often identified gamification as existing entirely as a business practice, related to 'airline rewards programs' that are 'attractive to marketers' (2015). Some argued that gamification could be debilitating in how it had been applied in digital journalism given the "pressure to make numbers' in the field (2014). It was a discourse that reinforced traditional norms separating news and business functions (see Artemas et al., 2018). It was also believed that gamification pushed the bounds of normative journalistic practice given that games were designed to encourage behavior and practice that would fit more in line with a journalistic advocacy role than with traditional roles associated with neutrality and objectivity (2017). For example, it was believed that news games could be 'used to persuade, many times without the player realizing that the game is specifically designed to shift or influence their thinking' (2015). Such activity - it was suggested - abridged ethical rules.

Yet, most of time, journalists saw gamification as squarely within journalism's traditional norms and practices. Journalists have long seen a dissemination role as central to their social duties; and here gamification was just another way of 'conveying information' (2011). The editorin-chief of USA Today saw gamification as an extension of - and in some ways an improvement on - what journalists have done all along. 'I think it really helps people understand the news. It's another way of telling the story and helping educate, and in some cases, entertain people' (2015). Gamification, in other words, built on existing journalistic skills.

When you're a journalist you have to understand the topic you are talking about globally, and you have to think about the situation and what are the elements that made the situation the way it actually is right now ... That's exactly what a game designer does. It's almost the same thing (2015).

Thus, gamification still required sound journalistic judgment. For example, one gaming journalist reassured interlocutors, 'we were cognizant throughout of the gravity of our subject and asked ourselves each step of the way whether our interactive offered a fair and accurate representation of the refugee experience' (2017). Gamifying the news did not stand in the way of doing good journalism. Journalists saw gamification as compatible in terms of storytelling (2015), the related - and already-cemented - use of interactive graphics, and the desire to keep readers 'actively engaged' (2013).

The discourse also positioned gamification as a way to overcome some of journalism's nagging shortcomings. 'Finding new ways to tell stories to younger audiences is a common concern among 
journalists; news gamification is just one of these ways' (2016). Thus, it was argued, 'games allow us to experience things that other storytelling formats don't get to do' (2016). Advocates promised, 'Games communicate differently than other media: They simulate processes rather than telling stories. For this reason, games are great at characterizing the complex behavior of systems' (2011). Gamifying the news could engage 'audiences with otherwise complex content' (2015). It had lessons to teach journalists about how to 'reach, inform, and engage our readers' (2013) and to 'target a millennial audience, as well as boost engagement' (2014).

A relatively recent trend in journalism has been the valorization of engagement as an emergent journalistic norm (see e.g. Holton et al., 2016; Lawrence et al., 2018). As already suggested, this was on full display in the metajournalistic discourse about gamification. Gamification was often positioned as befitting the goals of engagement. Gamifying the news provided the means for individuals to have a first-hand experience with news events, such as the bombing of Aleppo, a hurricane in Haiti, the challenges of operating a family farm, a food line in Los Angeles, or violence on the US-Mexico border. These news games engaged audiences to 'feel empathy for the real-life people involved in the event' (2016). News games allowed players to 'feel an emotion more powerfully than any other medium', giving consequence to the topic at play (2013) and leading to 'deeper thinking about an issue' (2015). According to one documentary journalist turned game designer, 'Once I started working in this format, once the technology kind of caught up, to me it has a whole different impact than a documentary film - extremely visceral, extremely deep' (2015). Simply put, news games 'engage users in a highly meaningful, memorable and influential way' (2013).

In other metajournalism, discourse focused on engagement as directed at the news product itself. A journalist-game designer noted, 'When you read an article, of course you want to read the article until the end, but you can always stop because you're distracted'. But, gamification, he argued, pulled readers in and kept them to the end. 'The reader's engagement is very strong' (2015). Simply put, gamification encouraged the audience to 'engage longer' (2012). Meanwhile, one news game that attracted much attention invited players to engage in playing the role of an investigative journalist. The hope was that journalism would be more valued as a result. There were hints in the discourse that the engagement that came with gamification might not be wholly good. For example, engagement relied on 'addictive' - and hence exploitive - behaviors (2015). Nevertheless, news engagement was such a self-evident good, in the discourse, that the goal of engagement was rarely questioned.

In response to RQ2, signs of skepticism appear, largely based on worries about market-driven motivations, but also out of concern that it might be a form of advocacy journalism. However, the discourse overwhelmingly places gamification within journalism's normative boundaries. The discourse largely came in two phases, focusing early on how gamification did what journalism had historically always done before shifting slightly to gamification's potential to achieve emergent engagement goals. Gamification fit within journalism's moral framework, hence reinforcing journalism's social obligations.

\section{Legitimizing gamification; indexing journalistic values}

Legitimizing discourses about gamification far outweighed delegitimizing discourses. As a general practice, gamification was occasionally seen as exploitive. For example, one trade publication argued that audience data were sometimes abused 'to trivialize or gamify the relationship with readers' (2014). Such practices left players 'measured and monitored' (2014). When applied to 
journalism, some believed gamification could 'degrade journalistic practice' (2016). Some discourse saw the practice as controversial, as an 'ugly neologism that has seen terrific hype and terrific backlash' (2014). There were early skeptics who found 'gaming-for-good' as naïve and 'cringe-inducing' (2011). Another skeptic saw gamification as a bad sign for journalism: 'If people can't process news without having it turned into a game for them, something's tragically wrong' (2011). Thus, delegitimizing discourses subtly tied gamification to market logics that did a disservice to audiences. Journalism's social obligations are seen as incompatible with economic motives. Anyone who couldn't see this must be naïve - a biting insult to self-styled savvy journalists (see Fallows, 1996).

Discourse about gamifying the news acknowledged such criticisms and thus acknowledged existing institutional values. In fact, 2011 saw a sustained volley of back-and-forth discourse prompted by criticisms of gamifying the news. But nearly all those criticisms were dismissed as outdated or misguided. It was the 'progressive editor' that pursued gamification (2015). These were not just games, they were 'social impact game(s)' (2013), 'games with a purpose' (2011), 'purpose-driven gaming' (2017), and '(s)mart gamification' (2013). Here too, discourse anticipated critical interlocutors. Gaming was more than entertainment. Likewise, an advocate argued, 'While traditional methods of newsmaking like writing and broadcasting may seem more sophisticated and respectable than videogames in theory, the opposite is true in practice' (2011). This discourse confronted notions that games were somehow incompatible with the serious business of journalism.

The discourse might acknowledge that '(g)amification got a deservedly bad wrap for being kind of cheesy' but that those problems had been addressed with games that treated serious issues respectfully (2015). Gamification wasn't naïve or market-driven fluff; it was serious. 'Most people think that games have to be trivial, they are not fitted to serious topics', a journalist-game designer complained. 'If you can make movies or you can make comic books on serious issues, why couldn't you make video games about that?' A newspaper games editor offered a similar defense, dismissing criticisms as a misunderstanding of games. 'It is, in short, an old-fashioned moral panic, a dated reaction to a medium that has been maturing for over 40 years' (2015). Indeed, resistance to gamification was little more than stodginess - stodginess that stood in the way of improving journalism's fate. 'Take investigations out of the ivory tower, and stop preaching to the converted and try to bring it to a different audience' (2015). Thus, journalists gave full-throated legitimacy to gamifying news. In doing so, they indexed journalism's values. Journalism was a progressive, serious and respectful endeavor, it was not old-fashioned, stodgy, or aloof.

At the same time, the discourse also provided an index of journalists' wishes. The legitimizing discourse mostly pointed to a practice that hearkened a coming phase of technological and economic solutions to journalism's problems. As one publisher said about gamification, 'We are excited about the future and what the dynamically-evolving media landscape has in store for us' (2012). It was promised that gamification 'blazed important trails to where journalism is headed' (2011). The discourse connected gamification with other technology-driven and future-oriented trends in journalism, such as 'QR codes, augmented reality' (2011), virtual reality, 360-video, and wearables. Gamification was promoted as 'the next big technological breakthrough for receiving news' (2011) and as something that needed to be 'on the radar on every news organization' (2011). As early as 2006 and as late as 2016, gamification was promoted as the future of media and 'the next generation' of journalism (2016).

The discourse also legitimized the practice by showing examples of gamification that were currently being published by reputable news entities, such as ProPublica, the Washington Post, 'the 
BBC, the Guardian, and the New York Times' (2015), and by portraying journalism schools as already onboard with gamifying news (2015). Gamification had arrived. And by linking it to established social media, such as Foursquare and Twitter (2013), the discourse indicated the degree to which the principles of gamification were already widely applied and 'approaching ubiquity' (2017). Here the discourse portrayed gamification as an already institutionalized form of journalism.

Meanwhile, gamification need not be feared, according to advocates, because it was really an extension of what news organizations have nearly always done. In fact, 'for those who think of game strategies as an innovation', journalists were reminded that crossword puzzles and similar games had a long history (2015). As already suggested, the discourse legitimized gamification by arguing it could overcome past problems and make important news engaging again. It could take news that was thick with statistics and 'do so much with it' (2015). Gamification, then, was the future, it was the present, and it was consistent with journalism's storied past. Journalism could be proud of its historic value system and proud of the vitality of this system to enfold new practices that achieved traditional aims.

However, there was another, entirely different kind of legitimization. Legitimizing discourses could be unabashedly utilitarian: gamification simply worked. When journalists talked about gamification broadly - outside of journalism per se - they saw an engaging and successful practice. The same was true when journalism embraced gamifying the news. As one journalist put it, 'gamification has worked very well for us. We launched a badge and achievements program ... and have seen a considerable increase in the amount of content we get and the level of engagement' (2011). Another journalist wrote that same year: ' $70 \%$ of large companies will use the techniques for at least one business process' (2011). A publisher was described as 'using gamification to get logins, engagement, and subscriptions. Eight months in, the company has grown traffic and advertising revenue' (2019). A headline promised details on how one platform had 'gamified journalism for 1.3 billion monthly page views' (2014); another headline offered the 'newsonomics of the newly quantified, gamified news reader' (2014). Simply put, gamification brought in people, clicks, and revenue.

Similarly, journalists legitimized gamification by connecting it to other popular media trends, such as Pokémon Go, which one journalist offered as 'proof that gamification ... works' (2017). In the search for revenue for news, the Apple Store provided a clear clue: 'apps with the highest revenues are games' (2016). Such utilitarian discourses ultimately undercut claims that gamification's value was ultimately in its ability to improve journalism, rather than just improve the bottom line. However, differences within the trade press came into focus here. Nearly all of this kind of discourse was aimed at publishers, editors, and others responsible for keeping news organizations afloat. The normative - rather than utilitarian - discourse was overwhelmingly aimed at working journalists. Here too the discourse was a negotiation - offering up legitimizing discourses that would win over one intended audience without alienating another audience.

When it came to RQ3, the discourse about gamification proved telling about journalism and journalists. Holdouts questioned the savviness of advocates of gamification. They remained skeptical of efforts that they perceived transgress the line between news and business functions, although this was less true of discourse aimed at management. However, for many journalists, the news-business divide was not the operative issue. Gamification was just another way to disseminate news - one of journalism's historic, core roles (see Vos, 2016). Above all, gamification promised to deliver goods seen as crucial in the digital age: audience engagement. Here, engagement emerged as a central journalistic norm. Journalism was a serious business - and so 
Table I. Gamification and the discursive construction of institutional change.

\begin{tabular}{|c|c|c|}
\hline Beliefs and values & $\begin{array}{l}\text { Gamification serves commercial ends } \\
\text { (via engaging new markets) }\end{array}$ & $\begin{array}{l}\text { Gamification serves public service ends } \\
\text { (via deep engagement with news) }\end{array}$ \\
\hline $\begin{array}{l}\text { Journalism is a } \\
\text { commercial institution } \\
\text { Journalism is a public } \\
\text { service institution }\end{array}$ & $\begin{array}{l}\text { (1) Gamification does not represent } \\
\text { institutional change } \\
\text { (2) Gamification represents institutional } \\
\text { change }\end{array}$ & $\begin{array}{l}\text { (3) Gamification represents institutional } \\
\text { change } \\
\text { (4) Gamification does not represent } \\
\text { institutional change }\end{array}$ \\
\hline
\end{tabular}

were news games. Those standing in the way of progress were merely stodgy. Journalism was constructed as a modern, adaptive institution, ready to meet journalism's obligations in new ways.

\section{Conclusions}

Institutional change cannot be theorized without theorizing journalism as a discursive institution. Indeed, the ontological reality of institutional change is itself discursively constructed. That is, the institution is understood to be changing or not changing based on the discursively constructed parameters of the beliefs and norms that constitute the institution (see Table 1).

The majority of the discourse analyzed here falls in the fourth quadrant in Table 1. Most of the discourse denotes beliefs that journalism is a public service and that gamification serves the public by deeply engaging readers with the news. Hence, the institutional boundaries of journalism remain unchanged by gamification's introduction and this is valued as a good thing. This also illustrates how institutions are inherently conservative (Parsons, 2007) - any change that rises to the level of institutional change will seemingly be seen as bad. Changes that affirm institutional values will be seen as good.

Clearly then, US journalism functions as a discursive institution (Hanitzsch and Vos, 2017). Journalists seek to discursively position new practices within the normative frameworks of the institution (Carlson, 2017). They discursively negotiate (Fürsich, 2009) through and past contradictions, settling on new scripts - 'gaming is serious', 'gamification is about deep engagement' to maintain the institution and help it adapt to new realities (Picard, 2014). Discursive institutionalism sees institutions 'both as structures that constrain actors and as constructs created and changed by those actors' (Schmidt, 2008: 314). The discourse analyzed here shows how this is so. Institutional actors have discretion in the institutional scripts they have at their disposal. Journalists who drew on a news-business divide script resisted gamification. For those who opted for an engagement-related script, gamification was a proper, right, and good practice. At the same time, it seems the overall normative outlook about journalism that journalists adopt, portends how they position gamification. While we can't know for sure why one script was chosen over another, we do see how journalists understood the state of journalism. Those who were guardians of journalism's traditional sensibilities found gamification questionable. Those who saw journalism as a modern, adaptive institution were quick to embrace gamification.

While there are contradictory discourses surrounding gamifying the news, a strong, consistent theme emerges. Audience engagement is key to the definition of gamification; it is engagement that places gamification clearly with the boundaries of normative journalism practices; and hence engagement in the serious matter of news is key to the legitimization of gamification. This 
discourse shifted focus away from seeing gamification as a drift toward entertainment and economic values.

There were a few inflections in the arc of the discourse. Gamification emerged at a time of enormous economic stress on journalism and this was - at least initially - a key theme in the discourse. Gamification, it was hoped - and sometimes feared - would be part of journalism's new economic model. We see that some of the initial scripts faded away; for example, the futurefocused discourse indeed saw gamification as 'magic attention machines' (Bogost, 2015), before offering a more nuanced focus on journalistic engagement. When the US-based Knight Foundation got behind gamifying news, a significant flurry of discourse on the topic emerged in 2011. This was also the time when critics offered their strongest criticisms. The advocates of gamification addressed these criticisms, sometimes implicitly, and discursively turned to engagement as a central legitimizing concept. This became a catalyzing moment where a new institutional script emerged. Gamification was not infotainment; it was serious business that allowed journalism to build on its strengths and do things it had heretofore struggled to do effectively. Iterations of this script then became the dominate discourse.

This discourse indicates the degree to which US journalists conceive of journalism as an exception in the use of gamification. It may be that, as Bogost (2015) argued, gamification is used as a tool to exploit audience expectations in the business and technology realms. But, according to the discourse analyzed here, journalism depends on audience attention in order to provide valuable, consequential information, and by doing so to enact its normative values. As journalists saw it, gamification provides an avenue to 'engage users' (Ferrer-Conill and Karlsson, 2016: 8) toward a realm with pro-social benefits. So, whereas gamification was sometimes seen as exploitive of players, journalists saw their own use of gamification as decidedly different, given that their serious social purposes were different.

Thus, the discourse about gamification also said much about US journalism more generally. Journalism had been hurting and new technologies, it was hoped, would provide answers. Audience engagement was central to journalism's role and hence to its social legitimacy (Holton et al., 2016; Lawrence et al., 2018). Journalism was about making a difference in people's lives - well constructed news led people to think deeply and critically and to act accordingly (Kovach and Rosenstiel, 2014). US journalism was believed to be a public good and, ultimately, the discourse about gamification settled on a script that only added to this belief.

\section{Funding}

The author(s) disclosed receipt of the following financial support for the research, authorship, and/ or publication of this article: This research was partially funded by the Donald W. Reynolds Journalism Institute.

\section{ORCID iD}

Tim P Vos (D) https://orcid.org/0000-0002-7174-5574

Gregory P Perreault (D) https://orcid.org/0000-0002-6645-1117

\section{References}

Artemas K, Vos TP, and Duffy M (2018) Journalism hits a wall: Rhetorical construction of newspapers' editorial and advertising relationship. Journalism Studies 19(7): 1004-1020.

Batsell J (2015) Engaged Journalism: Connecting with Digitally Empowered News Audiences. New York: Columbia University Press. 
Bogost I (2015) Gamification is bullshit. In: Waltz S and Deterding S (eds) The Gameful World: Approaches, Issues, Applications. Cambridge, MA: MIT Press, pp. 65-78.

Bogost I, Ferrari S, and Schweizer B (2010) Newsgames: Journalism at Play. Cambridge, MA: MIT Press.

Borger M, Van Hoof A, Costera Meijer I, et al. (2013) Constructing participatory journalism as a scholarly object: A genealogical analysis. Digital Journalism 1(1): 117-134.

Candlin CN (1997) General editor's preface. In: Gunnarsson B-L, Linell P, and Nordberg B (eds) The Construction of Professional Discourse. London; New York: Routledge, pp. viii-xiv.

Carlson M (2016) Metajournalistic discourse and the meanings of journalism: Definitional control, boundary work, and legitimation. Communication Theory 26(4): 349-368.

Carlson M (2017) Journalistic Authority: Legitimating News in the Digital Era. New York: Columbia University Press.

Carvalho A (2008) Media(ted) discourse and society. Journalism Studies 9(2): 161-177.

Coddington M (2015) The wall becomes a curtain: Revisiting journalism's news-business boundary. In: Carlson M and Lewis SC (eds) Boundaries of Journalism: Professionalism, Practices and Participation. London; New York: Routledge, pp. 67-82.

Cook TE (1998) Governing with the News: The News Media as a Political Institution. Chicago, IL: University of Chicago Press.

Fairclough N (1995) Critical Discourse Analysis: The Critical Study of Language. London; New York: Longman.

Fallows JM (1996) Breaking the News: How the Media Undermine American Democracy. New York: Pantheon Books.

Ferrer-Conill R and Karlsson M (2016) The Gamification of Journalism. Emerging Research and Trends in Gamification. Hershey, PA: IGI Global, pp. 356-383.

Fujikawa Y and Min M (2013) A new environment for algorithm research using gamification. In: 2013 IEEE international conference on Electro/Information Technology (EIT), Rapid City, SD, USA, 9-11 May 2013, pp. 1-6. New York: EIT.

Fürsich E (2009) In defense of textual analysis. Journalism Studies 10(2): 238-252.

Hamari J, Koivisto J, and Sarsa H (2014) Does gamification work? - A literature review of empirical studies on gamification. In: 2014 47th Hawaii international conference on system sciences (HICSS), Waikoloa, HI, USA, 6-9 January 2014, pp. 3025-3034. New York: EIT.

Hanitzsch T and Vos TP (2017) Journalistic roles and the struggle over institutional identity: The discursive constitution of journalism. Communication Theory 27(2): 115-135.

Holton AE, Lewis SC, and Coddington M (2016) Interacting with audiences. Journalism Studies 17(7): 849-859.

Huotari K and Hamari J (2012) Defining gamification: A service marketing perspective. In: Proceeding of the 16th international academic MindTrek conference, Tampere, Finland, 3-5 October 2012, pp. 17-22. New York: Association for Computing Machinery.

Jukes S (2019) Crossing the line between news and the business of news: Exploring journalists' use of Twitter. Media and Communication 7(1): 248-258.

King D, Greaves F, Exeter C, et al. (2013) 'Gamification': Influencing health behaviours with games. Journal of the Royal Society of Medicine 106(3): 76-78.

Kovach B and Rosenstiel T (2014) The Elements of Journalism: What Newspeople Should Know and the Public Should Expect. New York: Three Rivers Press.

Lawrence RG, Radcliffe D, and Schmidt TR (2018) Practicing engagement. Journalism Practice 12(10): $1220-1240$.

McGonigal J (2011) Reality Is Broken: Why Games Make Us Better and How They Can Change the World. Penguin: Vintage.

Nelson MJ (2012) Soviet and American precursors to the gamification of work. Proceeding of the 16th international academic MindTrek conference, pp. 23-26. New York: Association for Computing Machinery. 
Nicholson S (2015) A Recipe for Meaningful Gamification. Gamification in Education and Business. Berlin: Springer, pp. 1-20.

Parsons C (2007) How to Map Arguments in Political Science. New York: Oxford Press.

Picard RG (2014) Twilight or new dawn of journalism? Digital Journalism 2(3): 273-283.

Putnam RD (2000) Bowling alone: America's declining social capital. In: Crothers L and Lockhart C (eds) Culture and Politics. Berlin: Springer, pp. 223-234.

Schmidt T (2019) Rewriting the Newspaper: The Storytelling Movement in American Print Journalism. Columbia: University of Missouri Press.

Schmidt VA (2008) Discursive institutionalism: The explanatory power of ideas and discourse. Annual Review of Political Science 11(1): 303-326.

Schmidt VA (2010) Taking ideas and discourse seriously: Explaining change through discursive institutionalism as the fourth 'new institutionalism'. European Political Science Review 2(1): 1-25.

Schudson M (1978) Discovering the News: A Social History of American Newspapers. New York: Basic Books.

Schudson M (2001) The objectivity norm in American journalism. Journalism 2(2): 149-170.

Seaborn K and Fels DI (2015) Gamification in theory and action: A survey. International Journal of HumanComputer Studies 74: 14-31.

Tuchman G (1978) Making News: A Study in the Construction of Reality. New York: Free Press.

Vos TP (2012) 'Homo journalisticus:' Journalism education's role in articulating the objectivity norm. Journalism: Theory, Practice \& Criticism 13(4): 435-449.

Vos TP (2016) Historical perspectives on journalistic roles. In: Mellado C, Hellmueller L, and Donsbach W (eds) Journalistic Role Performance: Concepts, Models, and Measures. New York: Routledge, pp. 41-59.

Vos TP and Singer JB (2016) Media discourse about entrepreneurial journalism: Implications for journalistic capital. Journalism Practice 10(2): 143-159.

Werbach K (2014) (Re)defining gamification: A process approach. In: International conference on persuasive technology, pp. 266-272. New York: Springer.

Zelizer B (2004) Taking Journalism Seriously: News and the Academy. Thousand Oaks, CA: SAGE.

\section{Author biographies}

Tim P Vos (PhD, Syracuse University) is a professor and Director of the Michigan State University School of Journalism. Vos's research examines the roles of journalism, media sociology and gatekeeping, media history, and media policy. His work also explores how change has happened in print, broadcast, and digital news, public relations, and advertising.

Gregory P Perreault ( $\mathrm{PhD}$, University of Missouri) is an assistant professor of multimedia journalism at Appalachian State University. He is a media sociologist who examines how journalism narrates difference. $\mathrm{He}$ does this through exploration of norms and practices in journalism and the values that shape content in emerging technologies in journalism. 